Original scientific paper - Izvorni znanstveni rad

UDK: 637.041

\title{
Biocrystallization as method for distinguishing between organically and conventionally produced milk
}

doi: $10.15567 / \mathrm{mljekarstvo.2016.0402}$

\begin{abstract}
Anka Popović-Vranješ ${ }^{*}$, Tijana Lopičić-Vasić1, Goran Grubješić1 , Saša Krstović ${ }^{1}$, Dragomir Lukač ${ }^{1}$, Aleksandar Kralj², Uwe Geier ${ }^{3}$
\end{abstract}

${ }^{1}$ Department of Animal Science, Faculty of Agriculture, University of Novi Sad, Dositej Obradović Square 8, Novi Sad, Serbia ${ }^{2}$ Faculty of Agriculture, University of Banja Luka, Bulevar Vojvode Petra Bojovića 1A, Republika Srpska ${ }^{3}$ Forschungsring für Biologisch-Dynamische Wirtschaftsweisee.V., Brandschneise 5, Darmstadt, Germany

Received - Prispjelo: 08.02.2016. Accepted - Prihvaćeno: 20.10.2016.

\begin{abstract}
Holistic methods, such as biocrystallization and capillary dynamolysis, can be used to confirm differences in chemical composition between organic and conventionally produced milk. The utilization of such methods is complementary to other quality assurance methods and demonstrates a complex aspect of food quality. In this study, biocrystallization was used as a method for distinguishing between organic and conventionally produced pasteurized milk, demonstrating how the differences in the dairy cow feeding regime can affect milk properties. The biocrystallization was performed by means of copper (II) chloride dihydrate $\left(\mathrm{CuCl}_{2}{ }^{*} 2 \mathrm{H}_{2} \mathrm{O}\right)$. The biocrystallization patterns obtained from the conventional and organic milk samples were readily distinguished. A significant indication of differences was the emergence of degradation features in the biocrystallization patterns. While degradation features do not appear in organic milk, conventional milk showed clear indications of degradation, although the compound analysis of the two milks indicated no differences. From the morphological perspective, the biocrystallization patterns of organic milk have fared better according to all criteria. The results of the fatty acid analysis in milk from conventional and certified organic farms showed a greater content of beneficial fatty acids in organic milk: oleic $(\mathrm{P}<0.05)$, linoleic and linolenic $(\mathrm{P}<0.01)$. The analysis of animal feed indicated a higher content of cellulose, i.e. acid detergent fibers (ADF), and a lower content of neutral detergent fibers (NDF) in the organic animal feed. It was concluded that the method of copper chloride biocrystallization can determine the differences between pasteurized conventional and organic milk, which is greatly important in assuring the consumers of the milk origin, since the organic chain implies the increased quality control of soil, animal feed, animals and final dairy products with added value.
\end{abstract}

Key words: biocrystallization, holistic methods, organic milk, conventional milk

\section{Introduction}

The areas devoted to organic production in the Republic of Serbia have been increasing (Simić, 2014). The organic livestock production in Serbia encompasses sheep, cattle, pigs, goats, poultry, donkeys, horses, and bee societies. The total number of cattle in the Serbian organic livestock production in 2013 amounted to 2.176 heads, whereas in 2014 this number increased to 2.626 heads. With an

*Corresponding author/Dopisni autor: E-mail: anka.popovic@gmail.com 
increase in the arable land devoted to organic agriculture, the number of organic producers increased accordingly. In 2014, 1.867 producers were engaged in organic production in the Republic of Serbia. In 2013, 49 companies in the Republic of Serbia were involved in processing organic products, 33 in importing, and 23 in exporting. In recent years, the supply of imported processed organic products is increasing. According to IFOAM (International Federation of Agriculture Movements), the development of organic agriculture should be based on several basic principles: the principle of health, ecology, fairness, and environmental protection (http://www. ifoam.bio/en/organic-landmarks/principles-organicagriculture). The application of regulations and standards in relation to organic livestock production contributes greatly to the production of high quality and safe products (Popović-Vranješ et al., 2010a; 2011).

Holistic methods (such as biocrystallization, the rising picture method, and biophoton emission measurements) have been introduced in order to emphasize the benefits of organic food. However, the comparison of the chemical composition of foods is sometimes not sufficient to validate whether the food originates from the organic chain, i.e. whether it demonstrates potentials for exerting positive effects on human health (Matt et al., 2011). Using holistic methods is complementary to other methods of quality monitoring, which seem to relate to the complex concept of food quality.

The crystallization ability of $\mathrm{CuCl}_{2}$ is particularly influenced by the sample type. The fluid should be kept in a dish with a plastic ring of about $9 \mathrm{~cm}$ in diameter and a height of $1 \mathrm{~cm}$. The method of copper chloride crystallization varies slightly depending on the laboratory. According to the type of construction, 12 to 54 dishes can be fitted within the crystallization cabin at the same time. The decisive criteria are the ratio of the sample and copper chloride, and the conditions (the temperature and relative air humidity) which allow a certain evaporation time (the period between the formation of the first crystals and the crystallization of the last dish). Kahl et al. (2009) described in detail the copper chloride crystallization technique. Biocrystallization patterns using copper chloride are of weak greenish transparent color. Quality photos are made in the dark field (www.biodynamic-research.net).
Concerning milk reference series for the degradation and substance effect, researchers at the "Forschungsring für Biologisch-Dynamische Wirtschaftsweisee.V." had experience with some milk investigations (e.g. feeding, age and constitution of single cows; different kinds of ultrafiltration and microfiltration; x-ray detection). Based on previous studies, the concentration effects, degradation features and the optimum of concentration of cow's milk were detected.

Some other morphological features (Huber et al., 2010) proved valuable assessment of inadequate or insufficient quality:

a) Substance effect - describes whether samples require much or little substance to create similar biocrystallization patterns. The substance effect can be seen as the power aspect of quality.

b) Differentiation determines how accurate and differentiated the occurring features are. At the stage of optimum ripening, the differentiation is very high.

c) Integration shows how the different parts of the biocrystallization patterns appear to be respectively harmonious or separated. A highly integrated biocrystallization pattern can indicate a harmonious relation of growth and ripening of a plant (vitality).

d) Centre-coordination implies a positioning which is dependent on the evaporation process resulting in a radial supersaturated area around the geometric centre of the dish.

e) The biocrystallization pattern shows more or less clearly visible distinct stems - relative to each other, arising from the center and extending in the middle zone. More clear stems can be an indicator of ripening and less of degradation or aging.

f) Thinning out relates to the loss of structure in the outer and middle zone of the biocrystallization pattern. The texture is more or less empty with black areas without needles, which can be an indicator of ageing.

The features related to degradation/aging are the loss of structure and differentiation, biocrystallization patterns are more centered and chaotic, more asymmetry in the pattern, the loss of order, no clear stems formed, fragile stems and needles, the loss of the fullness of needles, thinning out, curly needles, curved needles, diagonally and crossed needles, and 
net structures. Doesburg et al. (2015) elaborated a concept to assess crystallization samples according to the features of degradation. Substance effect is described by Fritz et al. (2011).

The method of capillary dynamolysis, which is usually performed in parallel with biocrystallization, can differentiate between organic and conventional milk, as well as milk treated differently in processing (Popović-Vranješ et al., 2010b). Professor Catel showed in 1939 that raw milk was 3 to 10 times the nutritional value of pasteurized milk. Such milk lacks bactericidal substances present in raw milk. The method of biocrystallization also enables the detection of a high thermal treatment (Schmidt, 1980). In the Norwegian research (Hardeng and Edge, 2001) the health status of animals in organic and conventional production was monitored for three years. Consequently it was concluded that the management system of animals significantly affected the incidence of mastitis, ketosis and milk fever in cows. All these animal diseases reflect in the holistic quality of milk. Animal nutrition has a major impact on the quality of milk and consequently affects the chain of processing milk into dairy products (Popović-Vranješ et al., 2010c).

On the conventional farm, the Holstein Friesian breed of cows is exclusively present, whereas on the organic farm both the Holstein Friesian and Brown Swiss breeds are present. There are some documented differences between the fatty acid content among these breeds. In the research of DePeters et al. (1995), the milk fat of Holsteins contained a lower proportion of fatty acids ranging from C6:0 to C14:0 in comparison to Brown Swiss cows. The ratio of C18:1 to C18:0 was higher in Brown Swiss cows than in Holstein Friesian. The proportions of C 14:0, C 16:0 and C 18:2 did not differ among the breeds (DePeters et al., 1995). Organic and conventional milk did not significantly differ with respect to saturated fatty acid nor to trans fatty acid contents, but organic milk had significantly higher contents of polyunsaturated fatty acids (Collomb et al., 2008).

The purpose of this research was to demonstrate how the differences in the dairy cow feeding regime between conventional and organic farms can affect raw milk properties, and how conventional and organic milk can be effectively differentiated by the biocrystallization method, even after dairy plant processing.

\section{Materials and methods}

\section{Sample preparation for biocrystallization}

The milk was mixed with demineralized water (the volume ratio of milk and water was $25: 75 \%$, respectively) under shaking in order to achieve the patterns of the optimal milk concentration. The optimum concentration is based on the optimal experimental expression of the features. Three levels of milk concentration were used - low $(0.05 \mathrm{~mL})$, medium $(0.1 \mathrm{~mL})$ and high $(0.125 \mathrm{~mL})$. The solution was pipetted without filtering into glass tubes and $3 \mathrm{~mL}$ of a $5 \%$ solution of copper chloride was added subsequently. For each dish, $150 \mathrm{mg}$ of copper chloride was used. Missing amounts within the total volume of $6 \mathrm{~mL}$ were filled with demineralized water. Following a slight hand shaking of individual tubes, the solution was placed on the prepared dishes in the biocrystallization chamber.

\section{Copper chloride crystallization}

All the samples of different milk concentrations and production systems were analyzed in a day, whereas the whole experiment was repeated the following day. The experiment was carried out with a total of 12 biocrystallization patterns, 3 levels of concentration (0.05; 0.1 and $0.125 \mathrm{ml}$ of milk) with consistent amounts of $\mathrm{CuCl}_{2}$, in the Laboratory of the Institute "Forschungsring für BiologischDynamische Wirtschaftsweisee.V." in Darmstadt, Germany.

In this research, the criterion of ageing (degradation features) was used for the evaluation of the milk biocrystallization patterns. The method of visual evaluation was used for comparison. The samples were characterized using the reference biocrystallization patterns reflecting well-known physiological states such as ageing (degradation) and ripening, and physiological plant organs (seed, leaf, blossom, fruit, and root). If there was no empirical data available, determination of the optimal amount of good crystallization filtrate patterns had to be done on a preliminary experiment with different concentrations.

\section{Milk sampling and analyses}

The animal feeding practice on one conventional and one certified organic dairy farm in Serbia was monitored in the period from September to 
November 2015. The chemical composition, somatic cell count and the total number of bacteria were analysed in the samples of raw milk (100 bulk samples of conventional and 100 bulk samples of organic milk). These farms were selected because they supply milk to dairy plants from which the samples of processed milk were obtained, which renders the results as precise as possible. The milk processing followed the same standard procedure - high temperature short time pasteurization $\left(72^{\circ} \mathrm{C}, 15\right.$ seconds). During the research, pasteurized and standardized milk originating from these farms was acquired from the market (10 samples of conventional and 10 bulk samples of organic milk). The chemical composition of the collected samples was analysed and the samples were sent to the Institute in Darmstadt for the biocrystallization analysis. The differences in biocrystallization patterns between the processed conventional and organic milk were of particular interest in this research.

The milk analysis was performed in the Laboratory for Quality Control of Milk, the Faculty of Agriculture in Novi Sad, using a MilkoScan FT+ analyzer for routine compositional raw milk analysis employing Fourier Transform Infrared "FTIR". The MilkoScanTM FT+ techniques comply with: ISO 9622/IDF 141:2013 and the AOAC official method 972.16. Fossomatic FC was used for somatic cell counting in raw milk. BactoScanTM FC+ was used as a rapid method for determining the total number of bacteria in raw milk. The analyses were conducted according to the procedures outlined by Foss Electric.

The analysis of fatty acid content of milk was performed in the Laboratory for Quality Control of Animal Feed at the Faculty of Agriculture in Novi Sad. For the purpose of determining the milk fatty acids, a gas chromatograph with FID detector was used.

\section{Fatty acids methylation}

Fat was extracted from the milk/cheese samples using a Soxhlet extractor. About $20 \mathrm{mg}$ of fat was weighed in a $5 \mathrm{~cm}^{3}$ vial (Sigma-Aldrich, Switzerland) and $0.5 \mathrm{~mL}$ of $0.5 \mathrm{M} \mathrm{NaOH}$ was added. The vial was then heated to $70{ }^{\circ} \mathrm{C}$ for $10 \mathrm{~min}$ and cooled down to room temperature. Subsequently, $0.5 \mathrm{~mL}$ of boron trifluoride (Sigma-Aldrich, Switzerland) was added and the vial was reheated to $70{ }^{\circ} \mathrm{C}$ for
$10 \mathrm{~min}$ and cooled down to room temperature again. Finally, $1 \mathrm{~mL}$ of saturated $\mathrm{NaCl}$ solution and $1 \mathrm{~mL}$ n-heptane was added and gently mixed. The upper (heptane) layer was transferred into a $1 \mathrm{~mL}$ tube containing anhydrous sodium-sulfate. After $30 \mathrm{~min}$, the heptane layer was transferred into a GC vial and then analyzed.

\section{FAME analysis}

Column InterCap WAX (a length of $30 \mathrm{~m}$, an inner diameter of $0.25 \mathrm{~mm}$, a film thickness of $0.25 \mu \mathrm{m})$. The analysis of the standard mixture of methyl esters was carried out using the reference probe. The injector and detector temperatures were $260{ }^{\circ} \mathrm{C}$. Helium was applied as a carrier gas with a flow rate of $3 \mathrm{~mL} / \mathrm{min}$. The sample and standard were diluted in n-heptane (analytical purity). The sample of $1 \mu \mathrm{L}$ was placed in the injector. The fatty acid composition was calculated on the basis of the peak area. The results for the FAME content are expressed as mass fractions in percentage.

The analysis of animal feed was made in the Laboratory for Quality Control of Animal Feed at the Faculty of Agriculture in Novi Sad. The analysis of dry matter content, moisture, protein, fat and ash were carried out according to the Regulations on Sampling Methods and Methods of Physical, Chemical and Microbiological Analysis of Animal Feed (Official Gazette of SFRJ, 15/87). The content of nitrogen-free extracts (NFE) is obtained by computing and represents the interval between the number 100 and the sum of the values of moisture, protein, fat, cellulose and ash. The examination of crude fiber (cellulose) was carried out according to the AOCS (2005) procedure. The content of detergent fibers was determined by the Van Soest method (Van Soest et al., 1991).

\section{Statistical analysis}

The obtained data were statistically analysed by a t-test using the Statistica 12.6 software package. T-test analysis was performed in order to compare the samples of raw conventional and organic milk, as well as pasteurized conventional and organic milk. The analysis provided data on the average chemical composition in both, raw and pasteurized milk, somatic cell count and the total bacteria number of the examined raw milk, and average composition of fatty acids (\%) of pasteurized milk samples. 


\section{Results and discussion}

\section{Copper chloride biocrystallization}

\section{Low concentration $(0.05 \mathrm{~mL}$ of milk)}

The biocrystallization patterns of low milk concentrations $(0.05 \mathrm{~mL})$ reveal great differences (Figure 1$)$. The organic milk biocrystallization patterns appear to be significantly higher concentrated (substance effect) with well radiated needle branches (good center-coordination). Conversely, the conventional milk biocrystallization patterns indicate a very low concentration with thinning out in the middle zone and the irregular texture zone in the center. The center-coordination is low.
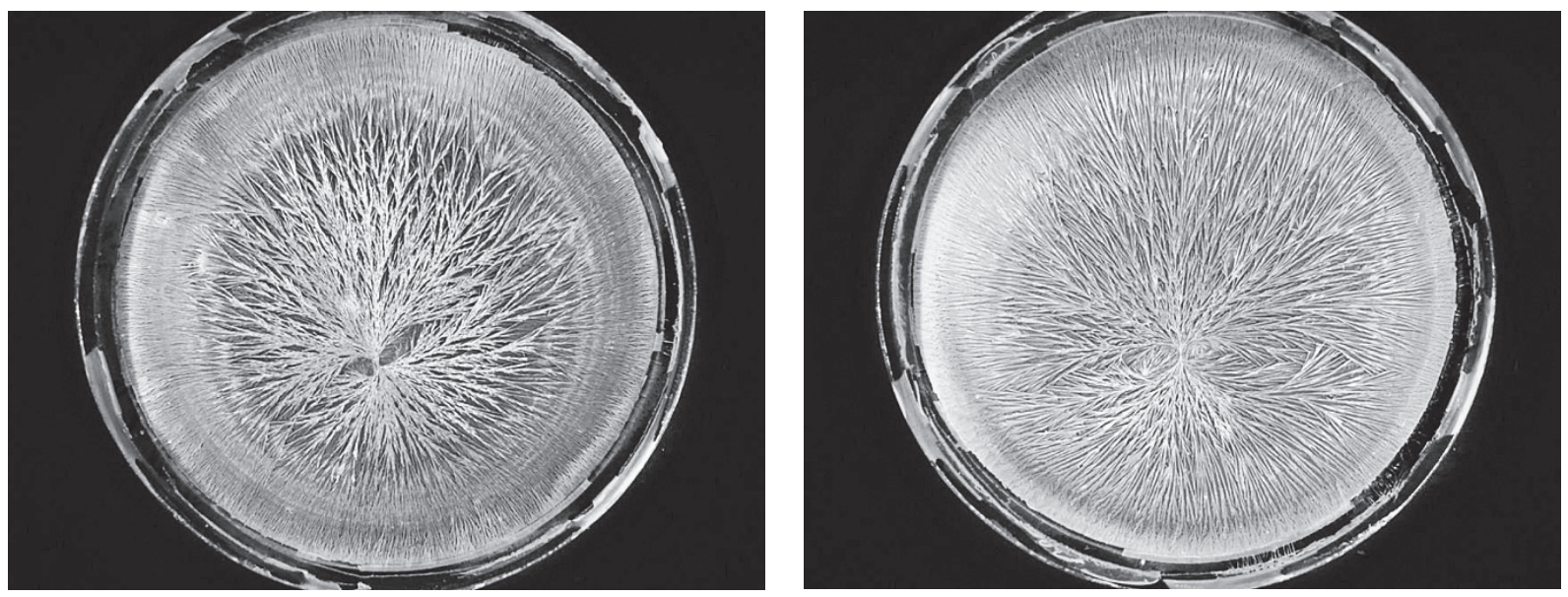

Figure 1. Biocrystallization patterns of pasteurized conventional and organic milk at low concentrations

\section{Medium concentration ( $0.1 \mathrm{~mL}$ of milk)}

At a higher concentration $(0.1 \mathrm{~mL}$ of milk), the conventional milk biocrystallization pattern appears concentrated to the same extent as the organic pattern with $0.05 \mathrm{~mL}$ milk. When comparing both the organic and conventional $0.1 \mathrm{~mL}$ biocrystallization patterns, the organic indicates a higher substance effect, a better center-coordination, and a greater integration. The irregular zone in the middle of the conventional milk image is a feature related to degradation (Figure 2).
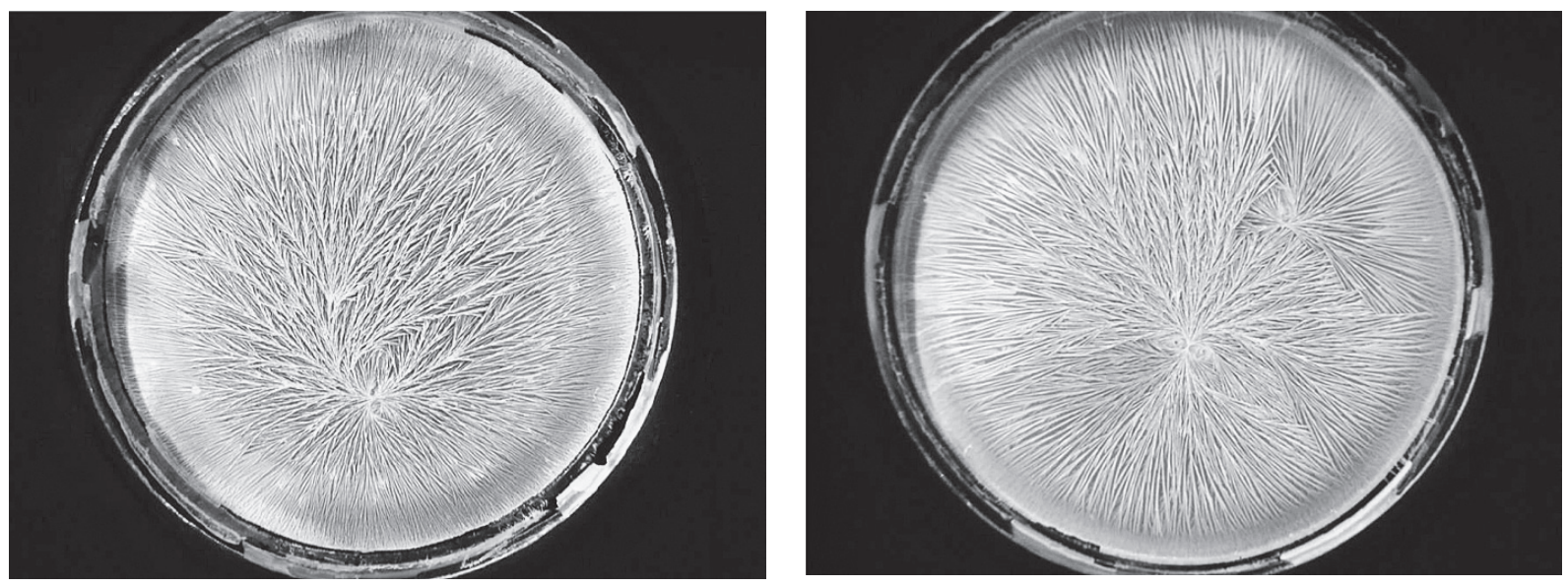

Figure 2. Biocrystallization patterns of pasteurized conventional and organic milk at medium concentrations 
High concentration ( $0.125 \mathrm{~mL}$ of milk)

The biocrystallization patterns with the highest concentration $(0.125 \mathrm{~mL}$ of milk) show the same results as the lower concentrations. The organic milk biocrystallization patterns better integrated, better center-coordinated and has a higher substance effect. The texture of irregular density in the middle of the conventional milk biocrystallization pattern is a feature of degradation. The organic milk indicates no degradation features (Figure 3).
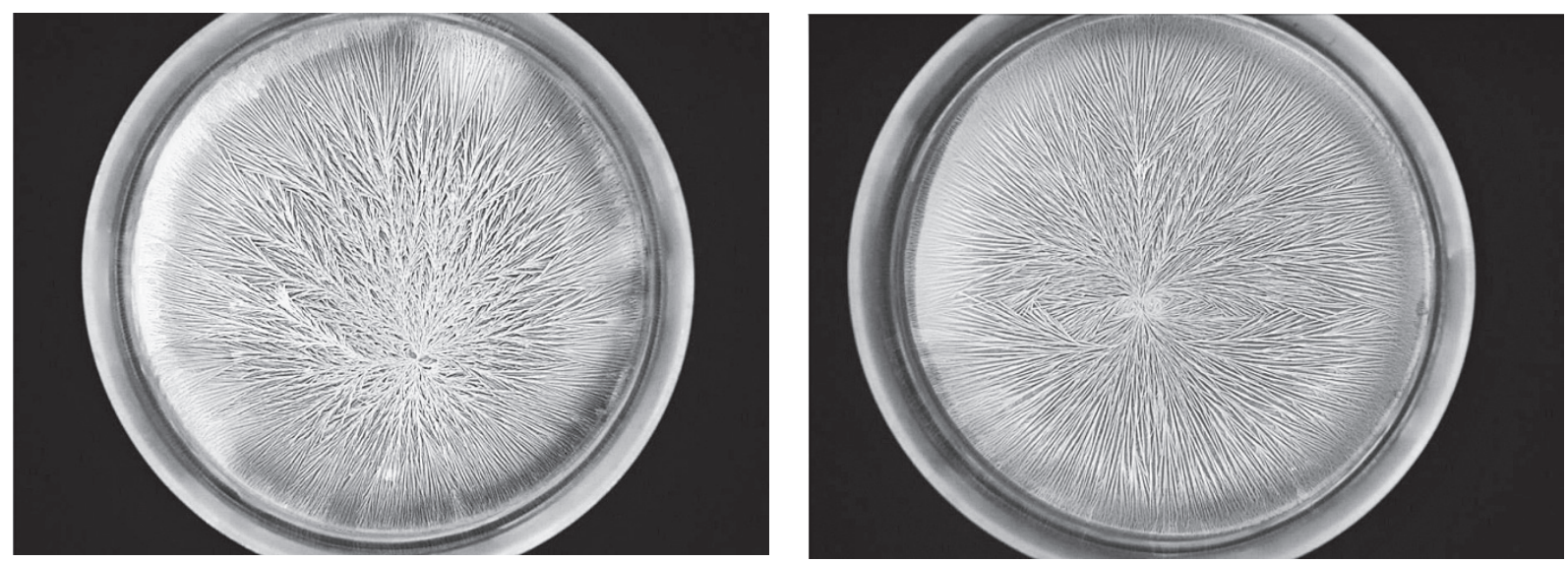

Figure 3. Biocrystallization patterns of pasteurized conventional and organic milk at high concentrations

The results obtained in this study correspond to other researches (Knijpenga, 1980; Huber et al., 2007; Bloksma et al., 2008; Kahl et al., 2009; Popović-Vranješ et al., 2012) and demonstrated clear differences between the conventional and organic milk samples, regardless of milk concentrations. The greatest differences occurred in the degree of degradation features, which were more notable in the conventional milk, and a significantly greater substance effect in the organic milk, with better central coordination and integration.

\section{Chemical composition and microbiological quality of conventional and organic milk}

Tables 1, 2 and 3 show the results of the analyzed raw conventional and organic milk samples.

Table 1. Average chemical composition, somatic cell count and the total bacteria number of the examined raw conventional and organic milk

\begin{tabular}{ccccccccc}
\hline & $\begin{array}{c}\text { Milk Fat } \\
(\%)\end{array}$ & $\begin{array}{c}\text { Protein } \\
(\%)\end{array}$ & $\begin{array}{c}\text { Yield } \\
(\mathrm{kg})\end{array}$ & $\begin{array}{c}\mathrm{DM} \\
(\%)\end{array}$ & $\begin{array}{c}\text { Lactose } \\
(\%)\end{array}$ & $\begin{array}{c}\text { MUN } \\
(\mathrm{mg} / \mathrm{dL})\end{array}$ & $\begin{array}{c}\text { SCC } \\
\left({ }^{*} 1000\right)\end{array}$ & $\begin{array}{c}\text { CFU } \\
\left({ }^{*} 1000 / \mathrm{mL}\right)\end{array}$ \\
\hline $\begin{array}{c}\text { Conventional } \\
\text { milk (n=100) }\end{array}$ & 3.76 & 3.25 & 12.60 & 12.49 & 4.52 & 22.25 & 389 & 27 \\
\hline $\begin{array}{c}\text { Organic milk } \\
(\mathrm{n}=100)\end{array}$ & 4.09 & 3.56 & 12.15 & 13.04 & 4.43 & 17.49 & 367 & 23 \\
\hline
\end{tabular}

DM - Dry Matter; MUN - Milk Urea Nitrogen; SCC - Somatic Cell Count; CFU - Colony Forming Units

Table 2. Average chemical composition of pasteurized conventional and organic milk

\begin{tabular}{ccccccc}
\hline & Milk Fat (\%) & Protein (\%) & DM (\%) & Lactose (\%) & DMWF (\%) & Casein (\%) \\
\hline Conventional milk $(\mathrm{n}=10)$ & 2.74 & 3.1 & 11.03 & 4.26 & 8.37 & 2.36 \\
\hline Organic milk $(\mathrm{n}=10)$ & 3.05 & 3.42 & 12.05 & 4.53 & 8.92 & 2.62 \\
\hline
\end{tabular}

DM - Dry Matter; DMWF - Dry Matter Without Fat 
No statistically significant differences were found in the analysis of chemical composition, somatic cell count and the total bacteria number of raw conventional and organic milk. It was noted that the average dry matter content was higher in organic milk (the average value was $13.04 \%$ ) than in conventional milk (12.49\%), which was reflected in a higher average content of milk fat and protein in organic milk. Milk urea nitrogen levels in both the conventional (22.25 mg/dL) and organic (17.49 mg/dL) milk indicated the optimal levels of energy and protein in animal feed (MUN levels from 15 to $30 \mathrm{mg} / \mathrm{dL}$ for milk protein levels from 3.0 to $4.0 \%$ ) (Senčić et al., 2011).

Upon analyzing the chemical composition of pasteurized conventional and organic milk a slightly higher dry matter content was noted in the organic milk samples $(12.05 \%)$ than in the conventional milk samples (11.03\%). No statistically significant differences were found in the analysis of the chemical composition of pasteurized conventional and organic milk.

The content of palmitic acid was significantly higher in the conventional milk $(\mathrm{P}<0.05)$, while

Table 3. Average composition of fatty acids (\%) of pasteurized conventional and organic milk

\begin{tabular}{ccc}
\hline & $\begin{array}{c}\text { Conventional } \\
\text { milk }(\mathrm{n}=10)\end{array}$ & $\begin{array}{c}\text { Organic milk } \\
(\mathrm{n}=10)\end{array}$ \\
\hline Butyric acid C4:0 & 1.71 & 1.61 \\
\hline Caprylic acid C8:0 & 1.22 & 1.25 \\
\hline Capric acid C10:0 & 2.93 & 3.22 \\
\hline Lauric acid C12:0 & 3.01 & 3.16 \\
\hline Myristic acid C14:0 & 9.71 & 8.91 \\
\hline Palmitic acid C16:0 & $\mathbf{2 9 . 7 4 ^ { \mathrm { a } }}$ & $\mathbf{2 5 . 8 9 ^ { \mathrm { b } }}$ \\
\hline $\begin{array}{c}\text { Stearic acid C18:0 } \\
11.43\end{array}$ & 9.44 \\
\hline Oleic acid C18:1 & $\mathbf{2 7 . 5 2 ^ { \mathrm { a } }}$ & $31.82^{\mathrm{b}}$ \\
\hline $\begin{array}{c}\text { Linoleic acid C18:2 } \\
2.91^{\mathrm{c}}\end{array}$ & $7.04^{\mathrm{d}}$ \\
\hline $\begin{array}{c}\text { Linolenic acid } \\
\text { C18:3 }\end{array}$ & $0.36^{\mathrm{c}}$ & $0.46^{\mathrm{d}}$ \\
\hline $\begin{array}{c}\text { Arachidic acid } \\
\text { C20:0 }\end{array}$ & 0.17 & 0.30 \\
\hline
\end{tabular}

\footnotetext{
a,b Means within a row marked with the different letter differ significantly $(\mathrm{P}<0.05)$

c,dMeans within a row marked with the different letter differ significantly $(\mathrm{P}<0.01)$
}

the oleic $(\mathrm{P}<0.05)$, linoleic and linolenic $(\mathrm{P}<0.01)$ acids were more present in the organic milk. The lower content of palmitic acid in the organic milk is beneficial to human health. The consumption of palmitic acid increases the risk of developing cardiovascular diseases (WHO, 2003). Oleic acid is the primary omega- 9 fatty acid found in the human body. Oleic acid exerts positive effects on reducing blood cholesterol levels. This reduction in cholesterol decreases the incidence of atherosclerosis and therefore the risk of heart attacks. In addition, oleic acid may aid in the prevention of certain cancer types (Win, 2005). It is known that supplanting saturated fatty acids with oleic acid and polyunsaturated fatty acids reduces the risk of cardiovascular diseases by lowering blood lipids, mostly cholesterol. Linoleic acid is an unsaturated essential fatty acid. Essential fatty acids are fatty acids that humans and animals must receive via food, because the body needs them and they cannot be synthesized in the body (Wohl et al., 1980). The term "essential fatty acids" refers to fatty acids required for biological processes.

\section{Analysis of animal feed}

Tables 4 and 5 show the composition of animal feed based on chemical analysis performed on the feed and broken down into its components. Each table shows the composition of the diet which was given on the conventional (Table 4) and organic (Table 5) farms. Upon looking at both tables it could be observed that the content of cellulose differs. In addition to that, there were differences noticed among the contents of acid (ADF) and neutral (NDF) detergent fibers of the feed. This occurred due to the consequential influence of the cellulose onto the ADF, but was somewhat unexpected in the case of NDF. In the aftermath it could be observed that the organic diet resulted in higher cellulose content $(19.51 \%)$ than the conventional diet (16.87\%). The occurring differences can be explained by principles of organic production. In the organic systems a larger share of roughage could be found than in conventional systems (Official Gazette of RS, 48/2011).

Hence, due to the fact that forages contained higher levels of crude fiber, the organic feed will usually have a higher content of cellulose, ADF, and NDF. Additional reason for the occurrence of differences lies in the fact that the proportion of 
corn middling in the conventionally prepared meal is higher, which leads to the feed not being abundant in fibre and ultimately having the impact on the reduction in the final instalment. By looking at the composition of the alfalfa hay in both farms it can be claimed that the organic system hay contains lower protein and ash content, while on the other hand, it has more fat and calcium content, which is important from the milk production perspective considering the importance of milk protein, fat and calcium contents to cheese-making practices.
Considering how differences in feeding regime influenced the fatty acid contents of processed conventional and organic milk, it can be assumed that the differences in biocrystallization patterns were caused by the differences in fatty acid contents, since the processing of both, the conventional and organic milk in the dairy plant was the same. Other factors that could affect the results of biocrystallization include the differences in the farming system.

Table 4. Average composition of cow's feed at the conventional farm (\% of dry matter)

\begin{tabular}{cccccccccccccc}
\hline $\mathrm{n}=5$ & $\begin{array}{c}\mathrm{AF} \\
(\mathrm{kg})\end{array}$ & $\begin{array}{c}\mathrm{DM} \\
(\%)\end{array}$ & $\begin{array}{c}\mathrm{DM} \\
(\mathrm{kg})\end{array}$ & $\begin{array}{c}\mathrm{CP} \\
(\%)\end{array}$ & $\begin{array}{c}\text { Fat } \\
(\%)\end{array}$ & $\begin{array}{c}\text { Celulose } \\
(\%)\end{array}$ & $\begin{array}{c}\text { Ash } \\
(\%)\end{array}$ & $\begin{array}{c}\mathrm{NFE} \\
(\%)\end{array}$ & $\begin{array}{c}\mathrm{Ca} \\
(\%)\end{array}$ & $\begin{array}{c}\mathrm{P} \\
(\%)\end{array}$ & $\begin{array}{c}\mathrm{ADF} \\
(\%)\end{array}$ & $\begin{array}{c}\mathrm{NDF} \\
(\%)\end{array}$ & $\begin{array}{c}\text { ADL } \\
(\%)\end{array}$ \\
\hline Alfalfa hay & 2 & 80.88 & 1.62 & 20.14 & 1.10 & 40.53 & 9.89 & 28.34 & 0.83 & 0.35 & 49.12 & 51.30 & 8.00 \\
\hline Alfalfa haylage & 5 & 26.67 & 1.33 & 21.25 & 3.20 & 35.21 & 11.86 & 28.49 & 1.74 & 0.35 & 45.53 & 51.03 & 9.91 \\
\hline Pea haylage & 3 & 33.58 & 1.01 & 19.89 & 2.36 & 25.05 & 10.72 & 41.99 & 1.71 & 0.34 & 35.59 & 38.82 & 7.77 \\
\hline Corn silage & 17 & 36.91 & 6.27 & 8.01 & 2.93 & 20.92 & 3.49 & 64.64 & 0.22 & 0.18 & 23.48 & 39.38 & 2.68 \\
\hline $\begin{array}{c}\text { Corn } \\
\text { middlings }\end{array}$ & 4 & 86.40 & 3.46 & 10.23 & 7.31 & 3.29 & 2.34 & 76.83 & 0.05 & 0.42 & 7.26 & 19.24 & 1.45 \\
\hline Concentrate & 8 & 89.00 & 7.12 & 19.01 & 3.99 & 9.92 & 7.22 & 58.85 & 1.04 & 0.85 & 8.26 & 21.41 & 1.38 \\
\hline Total & 39 & - & 20.81 & 14.51 & 3.87 & 16.87 & 5.96 & 58.45 & 0.69 & 0.48 & 19.57 & 31.53 & 3.15 \\
\hline
\end{tabular}

n - number of feed samples; AF - As Fed; DM - Dry Matter; CP - Crude Protein; NFE - Nitrogen-free extract; Ca - Calcium;

P - Phosporous; ADF - Acid Detergent Fiber; NDF - Neutral Detergent Fiber; ADL - Acid Detergent Lignin

Table 5. Average composition of cow's feed at the organic farm (\% of dry matter)

\begin{tabular}{|c|c|c|c|c|c|c|c|c|c|c|c|c|c|}
\hline $\mathrm{n}=5$ & $\begin{array}{l}\mathrm{AF} \\
(\mathrm{kg})\end{array}$ & $\begin{array}{l}\mathrm{DM} \\
(\%)\end{array}$ & $\begin{array}{l}\mathrm{DM} \\
(\mathrm{kg})\end{array}$ & $\begin{array}{l}\text { CP } \\
(\%)\end{array}$ & $\begin{array}{l}\text { Fat } \\
(\%)\end{array}$ & $\begin{array}{c}\text { Celulose } \\
(\%)\end{array}$ & $\begin{array}{l}\text { Ash } \\
(\%)\end{array}$ & $\begin{array}{l}\text { NFE } \\
(\%)\end{array}$ & $\begin{array}{l}\mathrm{Ca} \\
(\%)\end{array}$ & $\begin{array}{c}\mathrm{P} \\
(\%)\end{array}$ & $\begin{array}{l}\mathrm{ADF} \\
(\%)\end{array}$ & $\begin{array}{l}\text { NDF } \\
(\%)\end{array}$ & $\begin{array}{l}\text { ADL } \\
(\%)\end{array}$ \\
\hline Alfalfa hay & 3 & 90.79 & 2.72 & 18.64 & 1.31 & 34.68 & 7.91 & 37.46 & 1.12 & 0.28 & 44.18 & 44.18 & 11.15 \\
\hline $\begin{array}{l}\text { Alfalfa } \\
\text { haylage }\end{array}$ & 4 & 32.37 & 1.29 & 19.80 & 2.96 & 26.86 & 24.48 & 25.90 & 2.20 & 0.33 & 34.20 & 34.20 & 7.83 \\
\hline Corn silage & 23 & 29.26 & 6.73 & 7.30 & 1.77 & 27.05 & 5.61 & 58.27 & 0.40 & 0.15 & 31.41 & 31.41 & 4.71 \\
\hline $\begin{array}{l}\text { Oats and } \\
\text { pea mixture } \\
\text { haylage }\end{array}$ & 3 & 36.17 & 1.09 & 18.31 & 3.22 & 29.42 & 12.70 & 36.35 & 0.60 & 0.30 & 34.76 & 34.76 & 5.31 \\
\hline $\begin{array}{l}\text { Wheat } \\
\text { middlings }\end{array}$ & 1,5 & 88.82 & 1.33 & 17.80 & 4.67 & 9.01 & 4.90 & 63.32 & 0.08 & 0.64 & 10.75 & 32.12 & 3.61 \\
\hline Concentrate & 8 & 90.44 & 7.24 & 17.75 & 6.92 & 5.92 & 7.34 & 62.07 & 0.85 & 0.65 & 6.88 & 21.13 & 1.06 \\
\hline Total & 42,5 & - & 20.40 & 14.58 & 3.88 & 19.51 & 8.06 & 53.95 & 0.76 & 0.40 & 23.42 & 29.87 & 4.43 \\
\hline
\end{tabular}

n - number of feed samples; AF - As Fed; DM - Dry Matter; CP - Crude Protein; NFE - Nitrogen-free extract; Ca - Calcium;

P - Phosphorus; ADF - Acid Detergent Fiber; NDF - Neutral Detergent Fiber; ADL - Acid Detergent Lignin 


\section{Conclusion}

The biocrystallization patterns obtained by means of the crystallization method showed the differences between pasteurized organic and conventional milk. The biocrystallization patterns of the analyzed milk samples were readily distinguished. The differences were observed at all concentrations. The main difference was a significantly higher substance effect of the organic milk. Another important result is the occurrence of degradation features. While degradation features did not appear in the organic milk, the conventional milk showed clear indications of degradation. Regarding the morphological criteria, the organic milk biocrystallization patterns were ranked better. It was found that the method of copper chloride biocrystallization could effectively determine differences between organic and conventional milk, which is of great importance to consumer awareness and health.

The most salient factors of the quality differences between organic and conventional milk are: animal diet, management, health status and welfare, as well as milk processing procedures. The differences between the milk samples were based largely on the different diets of cows, i.e. whether organically or conventionally produced feeds were used. Therefore, the share of bulk feed and concentrate in the organic diet of cows was significantly changed in favor of forage and was based on the highest possible utilization of pasture. In organic systems, corn silage and dried forages (such as hay and alfalfa haylage) accounted for at least $60 \%$ of the dry matter in a cow's meal, which probably results in higher contents of beneficial oleic fatty acid and unsaturated linoleic and linolenic fatty acids in milk compared to conventionally produced milk.

\section{Biokristalizacija kao metoda za diferenciranje organski $i$ konvencionalno proizvedenog mlijeka}

\section{Sažetak}

Holističke metode, kao što su biokristalizacija i metoda kapilarne dinamolize ukazuju na razlike u kemijskom sastavu između organskog i konven- cionalnog mlijeka, a mogu imati pozitivan potencijalni učinak na zdravlje ljudi. Korištenje ovih metoda komplementarno je drugim metodama provjere kvalitete i pokazuje jedan aspekt kompleksnog koncepta kvalitete hrane. U ovom radu utvrđivana je razlika između pasteriziranog mlijeka proizvedenog u uvjetima konvencionalne i organske stočarske proizvodnje u Srbiji biokristalizacijom kao metodom za razlikovanje između organskog i konvencionalnog mlijeka. Rezultati pokazuju kako razlika u režimu hranidbe krava između konvencionalne i organske farme može utjecati na kvalitetu mlijeka. Biokristalizacija je izvršena korištenjem bakar (II) klorida $\left(\mathrm{CuCl}_{2}{ }^{*} 2 \mathrm{H}_{2} \mathrm{O}\right)$. Biokristalizacijski obrasci uzoraka konvencionalnog i organskog mlijeka lagani su za razlikovanje. Značajni pokazatelj razlika je pojava odlika degradacije biokristala. Dok se kod organskog mlijeka ne pojavljuje degradacija, konvencionalno mlijeko pokazuje čiste odlike degradacije. S morfološke strane, slike organskog mlijeka rangirane su bolje po svim kriterijima. Rezultati analize mlijeka podrijetlom s konvencionalne i certificirane organske farme pokazuju veći udjel blagotvornih masnih kiselina u organskom mlijeku, i to oleinske $(\mathrm{P}<0,05)$, linolne i linolenske $(\mathrm{P}<0,01)$. Analiza stočne hrane pokazala je viši sadržaj celuloze, kiselih (ADF) i niži sadržaj neutralnih (NDF) deterdžent vlakana u organskoj hrani. Zaključeno je kako se metodom biokristalizacije bakar kloridom može utvrditi razlika između pasteriziranog konvencionalnog i organskog mlijeka, što je od velikog značaja za informiranje potrošača glede podrijetla mlijeka, s obzirom kako organski lanac implicira strožiju kontrolu zemljišta, stočne hrane, životinja i gotovoga proizvoda s dodatom vrijednošću.

\section{Ključne riječi: biokristalizacija, holističke metode, organsko mlijeko, konvencionalno mlijeko}

\section{Acknowledgement}

The present paper is a result of the Project "Production of hard cheese with added value of milk produced in organic and selfsustaining systems" TR31095, funded by the Ministry of Education, Science and Technological Development of Serbia (2011-2016.). 


\section{References}

1. AOAC 972.16 (1972): Fat, lactose, protein and solids in milk (app. 1996).

2. AOCS (2005): Approved Procedure Ba 6a-05.

3. Bloksma, J., Adriaansen-Tennekes, R., Huber, M., van de Vijver, L. P., Baars, T., de Wit, J. (2008): Comparison of organic and conventional raw milk quality in the Netherlands, Biological Agriculture \& Horticulture 26 (1), 69-83. doi: 10.1080/01448765.2008.9755070

4. Collomb, M., Bisig, W., Bütikofer, U., Sieber, R., Bregy, M., Etter, L. (2008): Fatty acid composition of mountain milk from Switzerland: Comparison of organic and integrated farming systems, International Dairy Journal 18 (10), 976-982. doi: 10.1016/j.idairyj.2008.05.010

5. Doesburg, P., Huber, M., Andersen, J.O., Athmann, M., Van der Bie, G., Fritz, J., Geier, U., Hoekman, J., Kahl, J., Mergardt, G., Busscher, N. (2015): Standardization and performance of a visual Gestalt evaluation of biocrystallization patterns derived from ripening and decomposition processes, Biological Agriculture \& Horticulture: An International Journal for Sustainable Production Systems31 (2), 128-145. doi: /10.1080/01448765.2014.993705

6. DePeters, E.J., Medrano, J.F., Reed, B.A. (1995): Fatty acid composition of milk fat from three breeds of dairy cattle. Canadian Journal of Animal Science 75(2), 267-269. doi: 10.4141/cjas95-040

7. Fritz, J., Athmann, M., Kautz, T., Köpke, U. (2011): Grouping and classification of wheat from organic and conventional production systems by combining three image forming methods, Biological Agriculture \& Horticulture 27, 320-336. doi: 10.1080/01448765.2011.648918

8. Hardeng, F., Edge, V.L. (2001): Mastitis, Ketosis, and Milk Fever in 31 Organic and 93 Conventional Norwegian Dairy Herds, Journal of Dairy Science 84 (12), 2673-2679. doi: 10.3168/jds.S0022-0302(01)74721-2

9. Huber, M.A.S., Doesburg, P., van de Vijver, P.L. (2007): Biocrystallisations Milk Treatments: Milk Treatment Experimental Results. Louis Bolk Instituut, Driebergen, The Netherlands.

10. Huber, M., Andersen, J.O., Kahl, J., Busscher, N., Doesburg, P., Mergardt, G., Kretschmer, S., Zalecka, A., Meelursarn, A., Ploeger, A., Nierop, D., Van de Vijver, L., Baars, E. (2010): Validation of the visual evaluation of biocrystallizations. Development of a reliable and valid instrument for visual evaluation according to ISO-Norms for sensory analyses, Biological Agriculture \& Horticulture 27 (1), 25-40. doi: 10.1080/01448765.2010.10510428

11. ISO 9622:2013 (IDF 141:2013)

12. Kahl, J., Busscher, N., Doesburg, P., Mergardt, G., Huber, M., Ploeger, A. (2009): First tests of standardized biocrystallization on milk and milk products, European Food Research and Technology 229, 175-178. doi: 10.1007/s00217-009-1039-7

13. Knijpenga, H. (1980): Bildschaffende Methoden. In: Bockemuhl J.: Lebenszusammenhängeerkennen, erleben, gestalten. Naturwissenschaftliche Sektion der freien Hochschule für Geisteswissenschaft am Goetheanum, Dornach, 58-60.
14. Matt, D., Rembialkowska, E., Luik, A., Peetsmann, E. (2011): Quality of Organic vs. Conventional Food and Effects on Health, Report Published by Estonian University of Life Sciences, ISBN 978-9949-484-06-5.

15. Popović-Vranješ, A., Pejanović, R., Tomaš, M., GlavašTrbić, D. (2010a): Organska poljoprivreda - zdrava hrana - zdrava deca. Zbornik kratkih sadržaja, Simpozijum Stočarstvo, veterinarska medicina i ekonomika u ruralnom razvoju i proizvodnji zdravstveno bezbedne hrane, sa međunarodnim učešćem, 20-27. June, Divčibare, Serbia.

16. Popović-Vranješ, A., Krajinović, M., Grubačić, M.D, Kralj, A. (2010b): Biodinamička poljoprivreda kao poseban oblik organske poljoprivrede. Zbornik kratkih sadržaja, Simpozijum "Stočarstvo, veterinarska medicina i ekonomika u ruralnom razvoju i proizvodnji zdravstveno bezbedne hrane", sa međunarodnim učešćem, 20-27. June, Divčibare, Serbia.

17. Popović-Vranješ, A., Pejanović, R., Jovanović, S., Savić, M., Ostojić, M., Grubačić, M., Cvetanović, D. (2010c): Upravljanje kvalitetom $\mathrm{u}$ organskoj proizvodnji i preradi mleka, Prehrambena industrija - mleko i mlečni proizvodi 21 (1-2), 56-62.

18. Popović-Vranješ, A., Savić, M., Pejanović, R., Jovanović, S., Krajinović, G. (2011): The effect of organic milk production on certain milk quality parameters, Acta veterinaria 61 (4), 415-421. doi: 10.2298/AVB1 104415P

19. Popović-Vranješ, A., Pejanović, P., Cvetanović, D., Jevtić, M., Popović, M., Glavaš-Trbić, D., Jež, G. (2012): Primjena holističkih metoda $\mathrm{u}$ analizi organskog mlijeka, Mljekarstvo 62 (4), 284-290.

20. Schmidt, G. (1980): The dynamics of nutrition. Switzerland. ISBN 0-938250-00-0.

21. Senčić, Đ., Antunović, Z., Mijić, P., Baban, M., Puškadija, Z. (2011): Ekološka zootehnika, Poljoprivredni fakultet u Osijeku, ISBN 978-953-6331-96-3.

22. Simić, I. (2014): Organska proizvodnja u Republici Srbiji, unpublished data.

23. Official Gazette of SFRJ (1987): Pravilnik o metodama uzimanja uzoraka i metodama fizičkih, hemijskih i mikrobioloških analiza stočne hrane 15/1987.

24. Official Gazette of RS (2011): Pravilnik o kontroli i sertifikaciji u organskoj proizvodnji i metodama organske proizvodnje, 48/2011.

25. Van Soest, P.J., Robertson, J.B., Lewis, B.A. (1991): Methods for dietary fiber, neutral detergent fiber and non-starch polysaccharides in relation to animal nutrition, Journal of Dairy Science 74, 3583-3597. doi: 10.3168/jds.S0022-0302(91)78551-2

26. Win, D.T. (2005): Oleic acid - The anti-breast cancer component in olive oil, Assumption University Journal of Technology 9 (2), 75-78.

27. WHO (2003): Diet, nutrition and the prevention of chronic diseases. Report of a Joint WHO/FAO Expert Consultation. Geneva.

28. Wohl, M., Goodhart, R. and Shils, M. (1980): Modern Nutrition in Health and Disease. Lea \& Febiger, U.S.

29. https://www.ifoam.bio/en/organic-landmarks/principles-organic-agriculture (15.12.2015)

30. https://www.biodynamic-research.net (30.12.2015) 